\title{
СИНОНІМІЧНИЙ РЯД ДО СЛОВА ЩАСТЯ В УКРАЇНСЬКІЙ МОВІ
}

У статті на матеріалі тексикограбічних джерел схарактеризовано синонімічний ряд тексем до слова щастя в українській мові. Класифіковано одиниці, що становлять ядро, ближню, дальню й крайню периферію. Здійснено компонентний аналіз тексем синонімічного ряду з етимологічним коментарем, виокремлено їхні спільні семантичні характеристики. Виявлено смислові дублети слова щастя, а також окремі суперечності щодо опису семантики деяких синонімічних слів, що пов'язано з різним трактуванням аналізованих одиниць у лексикограбічній практиці.

Ключові слова: тексема щастя, синонім, синонімічний ряд, смисловий дублет, українська мова.

Ilienkova V. Synonymic Range to the Word "Happiness" in the Ukrainian Language. The synonym for the word happiness has not been considered yet in detail, that determines the scientific novelty and relevance of the study. The analysis of lexicographic sources demonstrates the synonymic series of the happiness token. The analysis and comparison of the tokens that belong to one synonymous series have been done.

The object of the study is a gentle zone of meanings embedded in the concept of happiness in the Ukrainian language, the subject of which is the constituents of the synonym for the word happiness. The purpose of our study is to select synonymous tokens for the word happiness, perform a component analysis of these tokens and identify common semantic characteristics that allow us to form a synonymous series with the dominant of happiness.

To achieve this goal, the following tasks are formulated: 1) to define synonyms for the word happiness; 2) to organize and classify them; 3) to determine the contextual significance of the identified synonymous units and the peculiarities of their functioning in the language world map of the Ukrainian world.

To achieve this goal, the following methods were used: continuous sampling (to obtain the body of the necessary synonyms), descriptive method (to qualify the features of lexical filling), component analysis (to identify features of the semantic structure of the synonymous series), as well as elements of quantitative calculation (to refine the results research).

Various uses of synonyms and their semantic doublets are investigated, special attention is paid to the description of synonyms within the vocabulary. In the course of the study, 15 vocabularies were analyzed and a semantic row for the word happiness was distinguished. It has been found that the word happiness has 23 synonyms 
(задоволення /pleasure/, благодать /gracel, блаженство /bliss/, талант/talent/, рай /paradise/, раювання /paradise/, гаразди /good/, удача /luck/, благополуччя /prosperity/, благо /good/, благоденство /prosperity/, фортуна /fortune/, доля / fate/, щастя-доля /happiness-fate/, радість /joy/, досягнення /achievement/, yсnіx/success/, талан /talent/, розкіш /luхиry/, жереб /lot/, солодощі /sweets/, призначення/destination/.

The synonyms analysis for the word happiness has demonstrated its semantic diversity. The word happiness has semantic doubles - joy and fate, although the last one has lost the meaning lately; there is some controversy over the description of the semantics of the following words such as таланm (talent) and талан (luck), as different vocabulary articles define their interchangeability differently.

Key words: token of happiness, synonym, synonymous series, semantic doublet, Ukrainian language.

\section{Вступ}

Одним з виявів динаміки мови є розвиток іiі синонімії. Лексична синонімія забезпечує точність і виразність висловлювання. Вона $€$ суттєвою для формування мовної картини світу, адже синоніми розширюють лексико-семантичний простір певної мови, збагачуючи іiі як відповідними словами, так і відтінками смислів, здатних передати особливості вербального «бачення» тим чи тим народом явищ довкілля. Тож синоніми виникають не лише з потреби мовців, а і як вияв можливостей самої мови словесно об'єктувати додаткові ознаки явища або відтворювати своєрідність його бачення в лексичному ресурсі.

Синонімія як мовний феномен наочно демонструє змістовий діапазон слів у тій чи тій мові, тому, аналізуючи синонімічний ряд до слова щзастя, можемо простежити смислову співвіднесеність мовних одиниць, близьких за значенням до нього, а також тих, що називають одне поняття, але відрізняються відтінками в значенні.

Здійснений у розвідці лінгвістичний аналіз передбачає розгляд семантичного наповнення лексеми щзастя й наявного в українській мові синонімічного ряду, конституенти якого містять відповідні семи. Поняття щастя належить до ідеальної, метафізичної, психоемоційної сфери буття людини, через що воно має ціннісну маркованість, більшою чи меншою мірою виявлену на лексико-семантичному рівні в словах, близьких за значенням до лексеми щзастя. Окрім універсальних смислів, актуалізованих у цій лексемі, маємо й такі, що відбивають уявлення про щастя кожного конкретного народу, зокрема й українського. 
Об’єктом дослідження є синонімічний ряд до слова щзастя в українській мові, предметом - конституенти досліджуваного синонімічного ряду. Мета дослідження - виявити спільні семантичні компоненти в словах, що формують синонімічний ряд з домінантою щзастя в українській мовній картині світу з огляду на ціннісні маркери відповідних слів-синонімів.

Лексичні синоніми мають чимале значення для розвитку мови, адже вони допомагають доповнити наші уявлення про предмети або явища й схарактеризувати їх у різних аспектах. Синонімічне багатство української мови $є$ однією з головних іï рис. Явище синонімії в лексиці полягає в можливостях добору різних слів для вираження уточнення й увиразнення того самого змісту, виділення різноманітних відтінків у характеристиці певного поняття з метою його оптимального позначення. Уживання мовцем синонімів свідчить про його розвинене мовне чуття, гнучкість у використанні вербального арсеналу, покликаного передати зміст повідомлення відповідно до ситуації спілкування.

Слова, які абсолютно тотожні або максимально наближені одне до одного, що розрізняються семантичними відтінками зі стилістичним забарвленням або цими ознаками одночасно, і називають синонімами (Дзюбишина-Мельник, Лаврінець, Симонова, Ціпцюра \& Ярошевич, 2018: 101). За іншим визначенням, синонімами називають слова, що співвідносяться з тими самими поняттями, мають одне загальне значення, але різняться відтінками лексичного значення, стилістичним забарвленням, сполучуваністю з іншими словами (Єpмоленко \& Бибик, 2001: 153).

Питання синонімії цікавили багатьох українських мовознавців, серед яких І. К. Білодід, Л. М. Бублик, М. А. Жовтобрюх, Л. А. Лисиченко, М. Я. Плющ, О. Д. Пономарів, О. О. Тараненко та ін. Щодо точності визначення синонімії загалом і синонімів зокрема й зараз точаться дискусії в науковому колі. Більшість з дослідників виділяє два напрями вивчення синонімів: 1) ті, що грунтуються на понятті про значення слова (О. А. Ахманова, Є. В. Кротевич); 2) в основі яких лежить явище дійсності або поняття (Р. О. Будагов, Є. М. Галкіна-Федорук, А. П. Євгеньєвна, М. А. Жовтобрюх, М. М. Шанський) (Лисиченко, 1997: 67). 


\section{Методи й методики дослідження}

Для досягнення поставленої мети було використано такі методи: суцільної вибірки (для отримання корпусу необхідних синонімів), описовий метод (для текстової презентації результатів дослідження), компонентного аналізу (для виявлення особливостей семантичної структури слів-конституентів синонімічного ряду), а також елементи кількісного підрахунку (для унаочнення результатів дослідження). Компонентний аналіз лексичного значення дає змогу змоделювати парадигму значень і багатозначного слова, і семантично близьких слівсинонімів. Значеннєві складники цих лексичних одиниць пов'язані спільним семантичним компонентом і структурно організовані співвідношенням: ядро $\rightarrow$ приядерна зона $\rightarrow$ периферія.

\section{Результати та дискусії}

Синонімія як вид парадигматичних відношень посідає належне місце у вивченні лексико-семантичної системи української мови. Тому, аналізуючи синонімічний ряд до слова щзастя, простежимо смислову залежність слів, близьких за семантикою до нього, і тих, що називають одне поняття, але відрізняються відтінками в значенні.

Абстрактні слова, які називають різні душевні стани людини, ускладнення, що викликають переживання, усвідомлення приємних чи неприємних ситуацій тощо, здебільшого об'єднуються в синонімічні ряди того самого емоційного наповнення (Русанівський, 1991: 4).

Синонімічний ряд до слова щзастя вивчали на прикладі англійської мови Н. Г. Єсипенко й I-I. Ю. Тим’як (Єсипенко \& Тимяк, 2014); сегментарно представлено вивчення синонімії з домінантою щзастя на матеріалі української мови в працях Н. М. Бобух (Бобух, 2006) та Л. М. Марчук (Марчук, 2014).

Для реалізації дослідницьких пошуків змоделюємо лексико-семантичне поле синонімів - ядерних репрезентантів поняття щастя. У ході дослідження було виявлено елементи, що наповнюють синонімічний ряд лексеми щзастя, за допомогою аналізу суцільної вибірки з 15 словників і тезаурусів української мови (Ващенко, 1972; ВШСУМ, 2012; Вусик, 2000; Деркач, 1993; Загоруйко, 2010; Караванський, 1995, 2014; Немировська, 2012; Поп, 2001; РУСС, 1995; СС, 2010; ССУМ 1999-2000; ССАО 2016; Собко, 2014; УСУЛ, 2009). 
Синонімічний ряд лексеми щзастя представлений словами з позитивною емотивно-оцінною маркованістю - задоволення, благодать, блаженство, талан, рай, раювання, гаразди, удача, благополуччя, благо, благоденство, фортуна, доля, щастя-доля, радість, досягнення, успіх, талант, розкіш, солодощі, призначення. Ядро склали лексеми, зазначені як синоніми в більшості джерел (тобто з показником 8-9). На противагу ядру є крайня периферія, яку становлять унікальні одиниці, що були зафіксовані або в одному словнику, або лише один раз у різних словниках (показник 1). Ближня й дальня периферії відповідно визначаються щодо середнього показника - 5. Ближню периферію становлять лексеми, зазначені як синоніми в більшості джерел (тобто з показником 5-7). Лексеми з показниками від 2 до 4 охоплюють дальню периферію.

Подаємо схематичне зображення синонімічного ряду до слова щзстя, де цифра в дужках означає кількість посилань на словосинонім в опрацьованих нами словниках (див. список використаної літератури).

Таблиця 1

\begin{tabular}{|c|c|c|c|c|}
\hline & Ядро & $\begin{array}{c}\text { Ближня } \\
\text { периферія }\end{array}$ & $\begin{array}{c}\text { Дальня } \\
\text { периферія }\end{array}$ & $\begin{array}{c}\text { Крайня } \\
\text { периферія }\end{array}$ \\
\hline $\begin{array}{l}\text { Мовні } \\
\text { одиниці, } \\
\text { вико- } \\
\text { ристані } \\
\text { в слов- } \\
\text { никах }\end{array}$ & \begin{tabular}{|l|} 
щастя, \\
доля (9), \\
радість (8)
\end{tabular} & \begin{tabular}{|l|} 
задоволення (7), \\
благодать (7), \\
блаженство (6), \\
талан (5), \\
удача (5), \\
фортуна (5)
\end{tabular} & $\begin{array}{l}\text { успіх (4), } \\
\text { рай (3), } \\
\text { щастя-доля (3), } \\
\text { гаразди (3), } \\
\text { раювання (2), } \\
\text { досягнення (2), } \\
\text { талант (2) }\end{array}$ & $\begin{array}{l}\text { розкіш (1), } \\
\text { солодощі (1), } \\
\text { призначення (1), } \\
\text { благополуччя } \\
(1), \\
\text { благо (1), } \\
\text { благоденство (1) }\end{array}$ \\
\hline
\end{tabular}

Характерним $є$ наявність жорсткого й компактного ядра, що становить 7\% від загальної кількості синонімів. До ядра, крім самої лексеми щзастя, уналежнюємо ще й такі лексеми, як доля й padicmb. Слово доля підсилює значення іменника щзастя, є синонімом до нього в контекстах, де йдеться про гарну, щасливу долю (Білоноженко, 1977: 76).

Одне зі значень слова доля - частина чого-небудь (СУМ, 1971:360). Від первинного значення виникло згодом і переносне, що є тотожним із семантикою слова щзастя. Адже, за етимологічним словником (Іларіон, 1994: 523), щзастя утворилося з префікса su-, що має значення 
«добрий», а čęstb - «частина», тобто добра частина, добра доля. Тож смисл слів щзастя й доля є спільним у тому разі, якщо йдеться про щасливу людину. Щасливою є людина, яка має гарну долю, тобто добру частину чогось. Про семантичну дублетність цих слів свідчить і народна творчість: Доля / щзастя як трясия, на кого схоче, на того й нападе. Без шзастя / долі й по гриби не ходять. Козак не без долі / щзастя, дівка не без щзастя / долі. Із часом ця смислова тотожність втратилася, адже доля - більш абстрактне поняття, семантично ширше, ніж слово щастя.

Ближня периферія охоплює синонімічні лексеми задоволення, благодать, блаженство, талан, удача, фортуна. Задоволення тлумачимо як позитивну емоцію, вдоволення або насолоду від чогось. Семантично близьким до слова насолода є слово блаженство, узяте з Біблії як відповідник вічному життю, тобто раюванню. Лексеми yдача й yсnіx можуть бути синонімами в певних контекстах завдяки семантичному зближенню з поняттям щзастя як радості від здійснення чогось, а слово фортуна в структурі свого значення містить семи «удача», «успіх», «доля», «талан».

Дальня периферія характеризується такими конституентами: успіх, рай, щастя-доля, гаразди, раювання, досягнення, талан, талант. Слово талан у першому значенні СУМ тлумачить як «доля, життєвий шлях кого-небудь; успіх, удача», у другому значенні ототожнює з талантом, хистом (СУМ, 1979: 26). Наявність синонімічних зв'язків у словах щзастя - талан - талант забезпечують як спільні поняттєві семи «досягнення», «успіх», так й позитивні емотивнооцінні, що ідентифікують талан як «успішну, щасливу долю».

Крайня периферія в досліджуваному синонімічному ряді найменш чисельна, що засвідчує нечастотне функціонування цих синонімів, - розкіш, солодомі, призначення, благополуччя, благо, благоденство (хоча семантично слова щастя, благополуччя, благо, блаженство є близькими й за кількістю спільних сем, і за частотністю контекстної взаємозамінюваності).

Кожен синонім із цього ряду виокремлює одну з ознак щзастя, його предметний чи поняттєвий маркер, що має для мовця певну цінність. Наявність спільних з поняттям щастя смислових компонентів і забезпечує введення того чи того синоніма до контексту. Так, слово розкіш уживають переважно із семантикою задоволення, щастя від 
чого-небудь матеріального, вартісного, красивого, багатого: Олена, яка зроду не розуміла жартів, знову напалася на Євдокима: - I це ти, очі твої безсовісні, хочещ, щзб на мене, як на якусь, панська челядь баньки витріщала? - Не все ж мені красуватися тобою: то багато розкоші для одного чоловіка (М. Стельмах). Зафіксований і діалектний відповідник слову щастя - пайда (щастя, талан): Як немає naйди, то й з хати не йди (Б. Грінченко).

У СУМі до слова щзастя подано три значення: 1. Стан цілковитого задоволення життям, відчуття глибокого вдоволення й безмежної радості, яких зазнає хто-небудь. 2. Досягнення, успіх, удача. 3. Доля, талан (СУМ, 1980: 575). Отже, за лексикографічним описом щзстя - це задоволення, радість, досягнення, успіх, удача, доля, талан. Семантично ці слова збігаються зі словом щзастя, що уможливлює використання їх як синонімів у певних контекстах. За значенням це логічна група синонімів, адже семантика кожного слова відрізняється додатковою ознакою самого явища. Ураховуючи поняття багатозначності, яке пов'язане з поняттям синонімії безпосередньо, стверджуємо, слід за О. Потебнею, що взаємозаміна слів із синонімічного ряду можлива лише в конкретній текстовій ситуації, а значення кожного слова загалом і синоніма зокрема розпізнаємо насамперед 3 контексту.

\section{Висновки}

Аналіз синонімічного ряду до слова щзастя продемонстрував його семантичне різноманіття. Слово щзастя має смислові дублети padicmь і доля, хоча останнє з плином часу втратило тотожність значення; існують деякі суперечності щодо опису семантики таких слів, як талан і талант, адже різні словникові статті по-різному визначають їх взаємозамінність.

Вивчення й опис семантичних можливостей слова щастя в динаміці $є$ перспективним для подальших досліджень.

\section{ЛІТЕРАТУРА}

1. Антоненко-Давидович Б. Як ми говоримо. Київ: Либідь, 1991. 256 с. 2. Білоноженко В. М. Щастя-доля. Культура слова. 1977. № 12. С. 76-80. 3. Бобух Н. М. Лексичні парадигми щзастя - нещастя й доля - недоля в поетичному словнику. Наук. вісн. Чернівецького ун-ту: зб. наук. пр. Слов'янська філологія. Чернівці: Рута, 2006. Вип. 276-277. С. 368-372. 4. Ващенко В. С. Синонімічний словник-мінімумів української мови. Дніпропетровськ: Рік, 1972. 92 с. 5. Вусик О. С. Словник українських 
синонімів: понад 1500 синонімічних гнізд / за ред. А.М. Поповського. Дніпропетровськ: Січ, 2000. 424 с. 6. ВШСУМ - Великий шкільний словник української мови / уклад. Т. К. Співак. Харків: ФОП Співак В. Л., 2012. 624 с. 7. Деркач П. М. Короткий словник синонімів української мови. Львів-Краків-Париж: Просвіта, 1993. 208 с. 8. Єрмоленко С. Я., Бибик С. П., Тодор О. Г. Українська мова. Короткий тлумачний словник лінгвістичних термінів. Київ: Либідь, 2001. 224 с. 9. Єсипенко Н. Г., Тим'як I-I. Ю. Синонімічний ряд номінативної лексеми happiness. URL: http://www. rusnauka.com/12_KPSN_2014/Philologia/3_165292.doc.htm. 10. Загоруйко О. Я. Великий універсальний словник української мови. Харків: Торсінг плюс, 2010. 768 с. 11. Ільєнкова В. В. Лексико-словотвірне гніздо з домінантою щастя та його дериваційна семантика. Закарпатські філологічні студіi. 2019. Вип. 11. Том 1. С. 11-16. 12. Караванський С. Практичний словник синонімів української мови. Київ: Кобза, 1995. 471 с. 13. Караванський С. Практичний словник синонімів української мови. Львів: БаК, 2014. 530 с. 14. Лисиченко Л. А. Лексико-семантична система української мови. Харків: ХДПУ імені Г. С. Сковороди, 1997. 130 с. 15. Марчук Л. М. Вербалізація концепту «щастя»: філософський та соціологічний аспекти. Наук. пр. Кам'янецьПодільського наи. ун-ту імені Івана Огієнка. Філол. науки. 2014. Вип. 35. С. 43-47. 16. Митрополит Іларіон. Етимологічно-семантичний словник української мови: у 4 т. Вінніпег - Канада: Волинь, 1994. Т. 4: П - Я. 536 с. 17. Немировська Н. Г. Словник синонімів та антонімів. Харків: Вид. група «Основа», 2012. 160 с. 18. Поп Д. І., Поп Д. Д. Русинський синонімічний словник з українськими відповідниками. Ужгород: Видво В. Падяка, 2001. 48 с. 19. Русанівський В. М. Семантична глибина слова. Мовознавство. 1991. № 2. С. 3-7. 20. РУСС - Русско-украинский словарь синонимов / под. ред. Н. Н. Пилинского, Н. П. Башнякова, Г. П. Вишневская. Київ: Освіта, 1995. 272 с. 21. Собко В. О., Демидчик Г. С., Вишник О. О. Словник синонімів, антонімів і найпоширеніших фразеологізмів для учнів початкових класів. Київ: Вид. дім «Освіта», 2014. 136 с. 22. СС - Словник синонімів / упор. М. С. Романець. Київ: Нац. книжковий проект, 2010. 144 с. 23. ССАО - Словник синонімів, антонімів, омонімів / уклад. I. О. Купіна. Харків: ТОВ «Вид. дім Весна», 2016. 96 с. 24. ССУМ - Словник синонімів української мови: у 2 т. / А. А. Бурячок, Г. М. Гнатюк, С. І. Головащук та ін.. Київ: Наук. думка, 1999-2000. Т. 2. 960 с. 25. СУМ - Словник української мови / уклад. І. К. Білодід. Київ: Наук. думка, 1980. Т. 11. 700 с. 26. УСУЛ - Універсальний словник української лексики. Синоніми, антоніми, омоніми. / уклад. Л. І., Нечволод, В. І. Бездітко. Харків: Торсінг плюс, 2009. 768 с. 27. Читай і знай! Довідник-практикум із сучасної української літературної мови / Н. Дзюбишина-Мельник, О. Лаврінець, К. Симонова, Л. Ціпцюра, І. Ярошевич. Київ: ВД «Києво-Могилянська академія», 2018. 415 с.

\section{REFERENCES}

1. Antonenko-Davydovych, B. (1991). Iak my hovorymo [As we speak]. Kyiv: Lybid [in Ukrainian]. 2. Bilonozhenko, V. M. (1977). Shchastia-dolia [Happiness is fate]. Kultura slova - Culture of word, 12, 76-80 [in Ukrainian]. 3. Bobukh, N. M. (2006). Leksychni paradyhmy shchastia - neshchastia y dolia - nedolia v poetychnomu slovnyku [The lexical paradigms of happiness - misery and destiny - are shortcomings in the poetic vocabulary]. Naukovyi visnyk Chernivetskoho un-tu. Slovianska filolohiia - Scientific Bulletin of Chernivtsi Univ. Slavic Philology. Chernivtsi: Ruta. Vyp. 276-277 [in Ukrainian]. 4. Vashchenko, V. S. 
(1972). Synonimichnyi slovnyk-minimumiv ukrainskoi movy [Synonymic dictionary of lows of the Ukrainian language]. Dnipropetrovsk: Rik [in Ukrainian]. 5. Vusyk, O. S. (2000). Slovnyk ukrainskykh synonimiv: Ponad 1500 synonimichnykh hnizd [Dictionary of Ukrainian Synonyms: Over 1500 synonyms]. Dnipropetrovsk: Sich [in Ukrainian]. 6. Spivak, T. K. (2012). Velykyi shkilnyi slovnyk ukrainskoi movy [Great school dictionary of the Ukrainian language]. Kharkiv: FOP Spivak V. L. [in Ukrainian]. 7. Derkach, P. M. (1993). Korotkyi slovnyk synonimiv ukrainskoi movy [A short dictionary of synonyms of the Ukrainian language]. Lviv-Krakiv-Paryzh: Prosvita [in Ukrainian]. 8. Yermolenko, S. Ia., Bybyk, S. P. \& Todor, O. H. (2001). Ukrainska mova. Korotkyi tlumachnyi slovnyk linhvistychnykh terminiv [Ukrainian language. A short explanatory dictionary of linguistic terms]. Kyiv: Lybid [in Ukrainian]. 9. Yesypenko, N. H. \& Tymiak, I-I. Iu. (2014). Synonimichnyi riad nominatyvnoi leksemy happiness [Synonymous with the nominative token of happiness]. Retrieved from http://www.rusnauka.com/12_KPSN_2014/Philologia/3_165292.doc.htm [in Ukrainian]. 10. Zahoruiko, O. Ia. (2010). Velykyi universalnyi slovnyk ukrainskoi movy [Great versatile dictionary of the Ukrainian language]. Kharkiv: Torsinh plius [in Ukrainian]. 11. Ilienkova, V. V. (2019) Leksyko-slovotvirne hnizdo z dominantoiu shchastia ta yoho deryvatsiina semantyka [The vocabulary-vocabulary nest with the dominant of happiness and its derivative semantics]. Zakarpatski filolohichni studii - Transcarpathian philological studios, 11 (1), 11-16 [in Ukrainian]. 12. Karavanskyi, S. (1995). Praktychnyi slovnyk synonimiv ukrainskoi movy [Practical Dictionary of Synonyms of Ukrainian]. Kyiv: Kobza [in Ukrainian]. 13. Karavanskyi, S. (2014). Praktychnyi slovnyk synonimiv ukrainskoi movy [Practical Dictionary of Synonyms of Ukrainian]. Lviv: BaK [in Ukrainian]. 14. Lysychenko, L. A. (1997). Leksyko-semantychna systema ukrainskoi movy [The lexicalsemantic system of the Ukrainian language]. Kharkiv: KhDPU imeni H. S. Skovorody [in Ukrainian]. 15. Marchuk, L. M. (2014). Verbalizatsiia kontseptu «shchastia»: filosofskyi ta sotsiolohichnyi aspekty [The verbalization of the concept of «happiness»: philosophical and sociological aspects]. Naukovi pratsi Kamianets-Podilskoho natsionalnoho universytetu imeni Ivana Ohiienka. Filolohichni nauky - Scientific works of Kamianets-Podilskyi Ivan Ogiyenko National University. Philological Sciences, 35, 43-47 [in Ukrainian]. 16. Mytropolyt, Ilarion (1994). Etymolohichno-semantychnyi slovnyk ukrainskoi movy [An etymological and semantic dictionary of the Ukrainian language]. (Vol. 4). Vinnipeh - Kanada: Volyn [in Ukrainian]. 17. Nemyrovska, N. H. (2012). Slovnyk synonimiv ta antonimiv [Dictionary of synonyms and antonyms]. Kharkiv: Vydavnycha hrupa «Osnova» [in Ukrainian]. 18. Pop, D. I. \& Pop, D. D. (2001). Rusynskyi synonimichnyi slovnyk z ukrainskymy vidpovidnykamy [Rusyn Synonymic Dictionary with Ukrainian Answers]. Uzhhorod: Vyd-vo V. Padiaka [in Ukrainian]. 19. Rusanivskyi, V. M. (1991). Semantychna hlybyna slova [Semantic depth of the word]. Movoznavstvo - Linguistics, 2, 3-7 [in Ukrainian]. 20. Pylynskoho, N. N., Bashniakova, N. P. \& Vyshnevskaia, H. P. (1995). Russko-ukraynskyi slovar synonymov [Russian-Ukrainian Dictionary of Synonyms]. Kyiv: Osvita [in Ukrainian]. 21. Sobko, V. O., Demydchyk, H. S. \& Vyshnyk, O. O. (2014). Slovnyk synonimiv, antonimiv $i$ naiposhyrenishykh frazeolohizmiv dlia uchniv pochatkovykh klasiv [A dictionary of synonyms, antonyms and common phraseologisms for elementary school students]. Kyiv: Vyd. dim «Osvita» [in Ukrainian]. 22. Romanets, M. S. (2010). Slovnyk synonimiv [Synonym Dictionary]. Kyiv: Nats. knyzhkovyi proekt [in Ukrainian]. 23. Kupina, I. O (2016). Slovnyk synonimiv, antonimiv, omonimiv [Dictionary of synonyms, antonyms, homonyms]. 
Kharkiv: TOV «Vyd. dim Vesna» [in Ukrainian]. 24. Buriachok, A. A., Hnatiuk, H. M. \& Holovashchuk, S. I. (Ed.). (1999-2000). Slovnyk synonimiv ukrainskoi movy [Dictionary of Synonyms of Ukrainian]. Kyiv: Nauk. dumka [in Ukrainian]. 25. Bilodid, I. K. (Ed.). (1980). Slovnyk ukrainskoi movy [Dictionary of Ukrainian Language] (Vol. 11). Kyiv: Nauk. dumka [in Ukrainian]. 26. Nechvolod, L. I. \& Bezditko, V. I. (2009). Universalnyi slovnyk ukrainskoi leksyky. Synonimy, antonimy, omonimy [Universal dictionary of Ukrainian vocabulary. Synonyms, antonyms, homonyms]. Kharkiv: Torsinh plius [in Ukrainian]. 27. DziubyshynaMelnyk, N., Lavrinets, O., Symonova, K., Tsiptsiura, L. \& Yaroshevych, I. (2018). Chytai i znai! Dovidnyk-praktykum iz suchasnoi ukrainskoi literaturnoi movy [Read and Know! Handbook of Contemporary Ukrainian Literary Language]. Kyiv: VD «Kyievo-Mohylianska akademiia» [in Ukrainian].

Ільєнкова Вікторія Віталіївна - аспірантка кафедри української мови, Харківський національний педагогічний університет імені Г. С. Сковороди; вул. Валентинівська, 2, м. Харків, 61168, Україна.

Tel.: +380969817935

E-mail: v.ilienkova@ukr.net

https://orcid.org/0000-0001-5707-3364

Ilienkova Viktoriia - Postgraduate Student, Ukrainian Language Department, H. S. Skovoroda Kharkiv National Pedagogical University; Valentynivska Str. 2, Kharkiv, 61168, Ukraine. 